N. Holovko, Ph.D. (pedagogical), Associate Professor,

S. Balashova, Ph.D. (pedagogical), Associate Professor, Taras Shevchenko National University of Kyiv, Kyiv, Ukraine

\title{
MODELING METHOD FOR PREPARING FUTURE EDUCATORS IN HIGHER EDUCATION INSTITUTIONS
}

\begin{abstract}
The article describes the essence of the concept of model and method of modeling; its use in the educational training process of future teachers. Analysis of scientific sources gives grounds to claim that the model of formation, scientists understand the system of interrelated elements of the pedagogical process, which provide a sufficient level of formation of students of socially significant qualities of the future specialist. The article also states that the purpose of pedagogical modeling is to create a functional system of organization of mastering the future knowledge of teachers and ways of their acquisition at the level of professional, subject-specific, and cultural aspects. Modeling is a method of cognitive and management activity, which allows to adequately and fully reflect in the model representations the essence, the most important qualities and components of the system (in our case training of masters for professional pedagogical activity), to receive information about its past, present and future status, conditions of construction, operation and development.

Keywords: model, method of modeling, training of future teachers, professional activity.
\end{abstract}

Formulation of the problem. Pedagogical activity is one of the most difficult. According to the educational training program, the teacher is a specialist who has special and versatile training, has a high level of spiritual culture, professional skill, endowed with certain professional abilities that characterize both the intellectual and emotional and volitional sphere of personality and on the basis of this professionally professional in different educational institutions. Developing a national education requires a creative approach to solving pedagogical problems. The application of the simulation method in the training of future teachers, orienting teachers to the achievement of the final learning outcomes, assimilates and efficient use of new technologies, develops a systematic vision for solving problems, serves as an effective factor in improving the quality of education. The modeling method plays a leading role in training masters for pedagogical activity.

Analysis of recent publications and studies. Scientists use the method of modeling quite widely in modern scientific and pedagogical scientific works (V. Grinyova, O. Dubasenyuk, N. Nichkalo, S. Sysoyeva, V. Chaika, V. Chernylevsky, etc.), in particular, the modeling of the future teacher's profession (V. Bespalko), N. Kuzmin, A. Markov, V. Slastionin). Application of modeling method in didactics (Yu. Lavrykov, V. Pikelna, G. Sukhobskaya, L. Friedman); modeling of pedagogical situations as a way of training future specialists (O. Berezyuk, O. Vlasenko, A. Dakhin, F. Zhikharenko, Y. Kulutkin).

The goal of the article is to reveal the possibilities of modeling in the process of training, personality formation and professional competence of a specialist, in particular the future specialists-educators.

Study presentation. The essence of the concept of model and modeling scientists interpret differently. Thus, O. Morozov defines the model in the general sense as an analogue (graphic, scheme, sign system, structure) of a certain object (original), a fragment of reality, artifacts, works of culture, conceptual-theoretical entities, etc. [7]. The model is an effective means of scientific research only in the most clear definition of their similarities and differences by theoretical means, which can determine the permissible limits of simplifications, abstractions, idealizations. By the physical nature of the model can be divided into: subject, sign (information), thinking. Having a significant place in the powerful arsenal of scientific means, fulfilling descriptive, explanatory and heuristic functions, the model plays an important role in the study of various complex phenomena of reality [7].

The term "model" is widely used not only in the scientific literature, and depending on the situation it has different meaning. The word "model" is derived from the Latin "modulus" which means measure, sample, norm. In the process of applying the modeling method, the model is used as a research tool. A model is a real, sign or mental system that reproduces, imitates, reflects the principles of the internal organization or functioning of an object, its properties, features or characteristics [7].

In the Ukrainian dictionary, the model is interpreted as "an example of any new product, a model copy of something. Item reproduced in a reduced, sometimes enlarged or in kind. A sample from which a mold for casting or reproducing in another material is removed "[8, P.776].

A more detailed concept of the model is found in the Great Interpretive Modern Ukrainian - this is a sample that reproduces the structure and action of any object is used to gain new knowledge about the object. What is material, kind for artistic image, reproduction. A sample from which a form for reproduction in another material is removed [1].

The model performs several functions: it clearly identifies the components that make up the system; schematically and realistically displays the connections between the components, in addition, the connections within the modeled object can be compared with the connections within the model; is a tool for comparative study of different features of the phenomenon, process.

In the Modeling Economics Glossary, the term "modeling" is interpreted as a way of exploring an object (process, phenomenon) with some simplified representation of it - a model; building and using models. Model building involves the presence of the subject (the researcher), the object of modeling and the purpose (purpose) for which it is carried out (sometimes the construction of the model is unnecessary - the subject finds it seemingly ready among physical objects or tangible products). The use of a model is based, first, on its ability to replace, replace an object for the purpose of the study, and secondly, its properties to be more accessible to study in a relevant aspect than the simulated object. The first is the similarity of the model to the object of modeling in that the purpose of the study is significant, the second - the simplification of those properties that are irrelevant for the purpose, but complicate the direct study of the object. Other model and object relationships are irrelevant. Modeling is the process of building, studying and applying models. The modeling process includes three system-forming elements: the subject of the study (system analyst); object of study; a model that mediates the relationship between the object being studied and the knowing subject (system analyst) [9]. 
Modeling is the creation, application, use of a model. The main functions of the model should be:

- simplifying the information about the properties of the object

- transfer of information and knowledge;

- managing and optimizing objects and processes;

- forecasting:

- diagnostics.

The concepts of "model" and "simulation" are an integral part of scientific research. It is both a method of presenting objects, phenomena and processes, and a means of verifying the truth of theoretical propositions, or experimentally establishing their validity. Any modeling process involves the presence of an active subject who defines the features of the modeling object as an object of interest, that is, the model only approximates the original. This means that one original object can fit many models, each of which is needed to solve a different specific task.

In the Philosophical Encyclopedic Dictionary, modeling is defined as the scientific method of indirect (indirect) study of objects of knowledge, the direct study of which for some reasons is impossible, difficult, ineffective or impractical, through the study of their models - subject, sign or thought systems that reproduce accordingly do they reflect certain characteristics (properties, features, principles of internal organization or functioning) of the originals [10].

To model - to create a model of something [8]. As a specific constructive-cognitive technique, a kind of presentation of processes and phenomena of reality, modeling has been known since ancient times. In the process of cognition, modeling works closely with other specific and general scientific methods, including experimental ones. Modeling actually gained the status of a general scientific method of cognition, became an effective theoretical and experimental means of research, which was first of all facilitated by intensive processes of mathematization and computerization of science. Computer (model-cybernetic) experiment, and subsequently its kind cognitive computer graphics - have become of unique importance in the study of complex processes and phenomena of reality, the verification of scientific hypotheses, the construction of theories. Using abstraction and idealization procedures, modeling allows for the sake of reproduction (in the model) and research to distinguish precisely the characteristics, parameters or properties of the modeled objects that are directly to be studied. The modeling process is characterized by a complex structure and includes the following main steps: problem formulation, model construction, its investigation, extrapolation of the results to the original. O. Moroz notes that the theoretical basis of modeling, which is manifested in various forms, depending on the scope and nature of the models used, is the theory of physical similarity, physical analogy and isomorphism of systems. According to the physical nature of models, there are three types of modeling: subject, sign (informational) and thinking. In close interaction with other methods of modeling plays an important role in the study of the most complex processes and phenomena of micro-, macro- and megaworld in revealing their deep essence [10].

Simulate - create a model of something, Investigate objects, systems, phenomena, processes through the construction and study of their models [1].

Scientific modeling is a method of studying phenomena and processes that is based on changing a particular research object (original) to another similar to it (model).

According to S. Goncharenko, the essence of modeling is to establish the similarity of phenomena (analogies), the adequacy of one object to another in certain respects, and on that basis transform the simpler in structure and content of the object into a more complex model (original). In other words, the model is an auxiliary tool that in the process of cognition, research provides new information about the main object of study [2].

Simulation is a specific learning technology that involves the organization, management and control of the learning process.

The scientific method of modeling in higher education institutions is used to bring the educational process closer to students' professional activities. In class, we choose this method because the model is a theoretically and practically organized structure that reproduces some or other part of reality in a schematic and visual form. By displaying or reproducing a research object, the model is able to replace it in such a way that its study gives us new information about that object.

In pedagogy, scientists determine that one of the important ways of finding ways to improve the quality of professional training of a specialist is to develop his model. According to $\mathrm{O}$. Savchenko, modeling is a method of researching objects on their analog models; building and studying models of real-life objects and phenomena and specially designed ones; in training, models are understood as content to be assimilated as a means of assimilation [6].

$O$. Dubaseniuk and other scientists consider the model as a real, symbolic or imaginary system, which reproduces the principles of internal organization and functioning, as well as certain properties, features or characteristics of the object of study, the direct study of which is impossible, difficult or impractical, and models of education - as formed by sign systems, mental analogues (logical constructs) that schematically reflect educational practice as a whole or its individual fragments. S. Witwitska notes that the model always acts as an analogy and is an intermediate link between advanced theoretical propositions and their validation in a real pedagogical process. Based on the understanding of the content of the concepts "model", "formation of socially significant qualities", under the model of formation, scientists understand the system of interrelated elements of the pedagogical process, which provide a sufficient level of formation of students of socially significant qualities of the future specialist [3].

Reference sources $[1,3,10]$ explain modeling as a method of knowing and transforming the world, which has spread with the development of science and led to the creation of new types of models that influenced the development of new functions of the method itself.

B. Maslov means modeling a purposeful process of constructive - projective, analytical - synthetic activity (based on the processing of existing information) in order to reflect the object as a whole or its characteristic components that determine the functional orientation of the object, ensure the stability of its existence and development [4].

Modeling as a method of scientific knowledge performs a number of functions:

- extrapolation and interpolation function (the model provides additional information about the object under study this function is performed by demonstrative, illustrative and educational-heuristic models);

- abstracting function (imaginary separation of a particular property or feature for the purpose of studying them more deeply);

- synthesizing function (the model can combine the properties of many different objects, phenomena and processes, and thus extend to objects that were not originally intended); 
- heuristic function (temporary switch from real object to imaginary - model);

- didactic function (use of modeling to increase the efficiency of the educational process) [3].

The main functions of modeling scientists include: descriptive, which due to the abstraction of the model allows you to simply explain the studied phenomena and processes; predictive - gives an opportunity to predict the future phenomena and states of the modeling systems and answers the question "what will happen"; normative, which is to answer the question "how should it be?", if besides the system, criteria for estimating its state are given, then by using optimization it is possible not only to describe the existing system, but also to construct its normative image from the point of view of sub ' The objective, interests and benefits of which are reflected in the criteria.

The variety of phenomena and processes of reality determines the many types and characteristics of models that can be classified as follows:

- by types of problem solving and purpose;

- the form, as a method of construction and the means by which the models are built;

- in content - in the nature of the objects that reproduce the models;

- by description methods:

a) deterministic, describing processes with clearly defined causes and effects;

b) probabilities describing the approximate processes, based on averaged random events;

c) heuristic, which are formed using technical means and persons possessing a certain intellectual level (new ideas, long-term forecasts, etc.);

d) combined;

- in completeness of similarity:

a) absolute, which requires complete identity of states or phenomena in space and time;

b) a complete resemblance when the processes occurring in the objects of modeling and in models change similarly in time and in space;

c) incomplete similarity when processes occurring in models and objects of simulation are similar to either in time or in space;

d) approximate similarity (analogy), when not all but the most significant factors influencing the processes occurring in the objects of modeling are taken into account in the models;

- by physical nature:

a) imaginary;

b) material. - in completeness of similarity:

a) absolute, which requires complete identity of states or phenomena in space and time;

b) a complete resemblance when the processes occurring in the objects of modeling and in models change similarly in time and in space;

c) incomplete similarity when processes occurring in models and objects of simulation are similar to either in time or in space;

d) approximate similarity (analogy), when not all but the most significant factors influencing the processes occurring in the objects of modeling are taken into account in the models;

- by physical nature:

a) imaginary;

b) material.

The basic principles of modeling professional activity in the educational process are the following: 1) systematic, accessible, consistent; 2) completeness of the developed model, that is, the system of proposed tasks should contain the full content of professional activity in a certain field; 3) communication of vocational-theoretical and vocational training; 4) task typing; 5) reproduction of subject and social content of professional activity, dynamics of production; 6) taking into account typical errors; 7) selection of appropriate forms, methods and techniques for solving problems.

Within the framework of the discipline "Modeling of professional activity of a specialist" we apply modeling of the content of educational material in terms of its structural and logical arrangement, schematization, visualization, suitable for use in the work with him types and methods of educational activity, etc. When completed, all this makes it possible to build a methodical system of teaching the subject with the support of common methods of scientific cognition and psychological and pedagogical patterns of cognitive activity of future educators.

In the process of modeling the preparation of masters for future pedagogical activity, it should be taken into account that there is a close connection between the content of the educational material and the future activity of the specialist.

Conclusions. Thus, we believe that modeling is a method of cognitive and administrative activity that allows to adequately and fully reflect in the model representations the essence, the most important qualities and components of the system (in our case - preparation of masters for professional pedagogical activity), to obtain information about its past, present and future status, opportunities and conditions of construction, operation and development. The analysis of the scientific-pedagogical literature gives grounds to claim that modeling becomes more relevant and promising in the direction of the development of pedagogical science. Simulation is an integral part in ensuring the unity of learning and research in the pedagogical process. Modeling is one of the methods of scientific study that is widely used in pedagogy. Modeling method is integrative, it allows to combine empirical and theoretical in pedagogical study, in particular, and in the course of studying a pedagogical object experiment with the construction of logical structures and scientific abstractions.

\section{References}

1. Velykyy tlumachnyy slovnyk suchasnoyi ukrayins'koyi movy (z dod. i dopov.) / Uklad. i holov. red. V.T. Busel. - K.; Irpin': VTF "Perun", 2005. 1728 s. S. 690.

2. Honcharenko, S. U. Pedahohichni doslidzhennya: Metodolohichni porady molodym naukovtsyam / S. U. Honcharenko. - K. ; Vinnytsya : DOV "Vinnytsya", 2008. - $278 \mathrm{~s}$.

3. Dubasenyuk O.A. Kontseptual'ni modeli pedahohichnoyi osvity naukovi poshuky i zdobutky//Profesiyno - pedahohichna osvita: suchasni kontseptual'ni modeli ta tendentsiyi rozvytku / Avt. kol. O.A. Dubasenyuk, O.YE. Antonova, S.S. Vitvyts'ka, O.V. Voznyuk, N.H. Sydorchuk ta in.//Za zah. red. prof. O.A. Dubasenyuk: Vyd-vo 2 - e dop. - Zhytomyr: Vyd-vo ZHDU im. I. Franka, 2008. - S. 8-28.

4. Maslov V.I. Kontseptual'ni zasady pobudovy, zmist i struktura oriyentovanoyi modeli funktsional'noyi kompetentnosti kerivnykiv navchal'nykh zakladiv. Pislyadyplomna osvita v Ukrayini, 2009, - №2, - s. 3-10.

5. Praktykum z pedahohiky: Navch. posib./Za zah. red. Dubasenyuk O.A., Ivanchenko A.V. - Zhytomyr: ZHDPU, 2002 - s. 40

6. Savchenko O.YA. Dydaktyka pochatkovoyi shkoly: Navchal'nyy pidruchnyk/Ukl. O.YA Savchenko. - K: Heneza, 1999 - $368 \mathrm{~s}$.

7. Slovnyk inshomovnykh sliv/ Uklad. S. M. Morozov, L. M. Shkaraputa. Kyyiv: Naukova dumka, 2000. $-680 \mathrm{~s}$

8. Slovnyk ukrayins'koyi movy: v 11 tomakh. - Tom 4, 1973. - Stor. 775.

9. Terminolohichno-tlumachnyy slovnyk "Modelyuvannya ekonomiky". 2015.

10. Filosofs'kyy entsyklopedychnyy slovnyk / NAN Ukrayiny, In-t filosofiyi imeni H. S. Skovorody, [redk. V. I. Shynkaruk ta in.] - Kyyiv: Abrys, 2002-VI. - 742 s.

Список використаних джерел

1. Великий тлумачний словник сучасної української мови (з дод. і допов.) / Уклад. і голов. ред. В.Т. Бусел. - К.; Ірпінь: ВТФ "Перун", 2005. 1728 c. - C. 690

2. Гончаренко С. У. Педагогічні дослідження : Методологічні поради молодим науковцям / С. У. Гончаренко. - К. ; Вінниця : ДОВ "Вінниця", 2008. -278 c. 
3. Дубасенюк О. А. Концептуальні моделі педагогічної освіти наукові пошуки і здобутки // Професійно-педагогічна освіта: сучасні концептуальні моделі та тенденції розвитку / Авт. кол. О.А. Дубасенюк, О.Є. Антонова, С.С. Вітвицька, О.В. Вознюк, Н.Г. Сидорчук та ін. // За заг. ред. проф. О.А. Дубасенюк: Вид-во 2-е доп. - Житомир: Вид-во ЖДУ ім. І. Франка, 2008. - С. 8-28.

4. Маслов В. І. Концептуальні засади побудови, зміст і структура орієнтованої моделі функціональної компетентності керівників навчальних закладів. - Післядипломна освіта в Україні, 2009. - №2. - С. 3-10.

5. Практикум з педагогіки : Навч. посіб. / За заг. ред. Дубасенюк О.А., Іванченко А.В. - Житомир: ЖДПУ, 2002 - С. 40
6. Савченко О. Я. Дидактика початкової школи : Навч. підруч. / Укп. О.Я Савченко - К: Генеза, 1999 - 368 с.

7. Словник іншомовних слів / Уклад. С. М. Морозов, Л. М. Шкарапута. К. : Наукова думка, 2000. - 680 с.

8. Словник української мови : в 11 т. - Київ, 1973. - Т. 4. - С. 775.

9. Термінологічно-тлумачний словник "Моделювання економіки". - К., 2015

10. Філософський енциклопедичний словник / НАН України, ІН-т філософрії імені Г. С. Сковороди, [редк. В. І. Шинкарук та ін.] - К. : Абрис, 2002VI. $-742 \mathrm{c}$

Надійшла до редколегії 18.01.20

Н. Головко канд. пед. наук, доц.,

С. Балашова канд. пед. наук, доц.

Київський національний університет імені Тараса Шевченка, Київ

\section{МЕТОД МОДЕЛЮВАННЯ ПІД ЧАС ПІДГОТОВКИ МАЙБУТНІХ ПЕДАГОГІВ У ЗАКЛАДАХ ВИЩОЇ ОСВІТИ}

У статті розкривається сутність поняття модель та метод моделювання; його використання в освітньому процесі під час підготовки майбутніх педагогів. Аналіз наукових джерел дає підстави стверджувати, що під моделлю формування науковці розуміють систему взаємопов'язаних елементів педагогічного процесу, котрі забезпечують достатній рівень сформованості у студентів соціально значущих якостей майбутнього фахівця. У статті також вказується, що метою педагогічного моделювання є створення функціональної системи організації засвоєння майбутніми педагогами знань і способів їх здобуття на рівні професійного, фахово-предметного, загальнокультурного аспектів. У процесі моделювання виявляється одна з найважливіших закономірностей системи: залежність цілісної структури від головних цілей, завдань системи. Моделювання - метод пізнавальної й управлінської діяльності, який дозволяє адекватно і цілісно відобразити в модельних уявленнях сутність, найважливіші якості і компоненти системи (у нашому випадку - підготовки магістрів до професійної педагогічної діяльності), одержати інформацію про їі минулий, теперішній і майбутній стан, можливості та умови побудови, функціонування і розвитку. У процесі моделювання виявляється одна з найважливіших закономірностей системи: залежність цілісної структури від головних цілей, завдань системи. Метою педагогічного моделювання є створення функціональної системи організації засвоєння студентами знань і способів їх здобуття на рівні професійного, фахово-предметного, загальнокультурного аспектів. Реалізація мети передбачає вирішення ряду завдань, зокрема підготовки висококваліфікованих конкурентоспроможних фахівців, активних суб'єктів професійної діяльності, здатних самостійно аналізувати виробничі ситуації та виробляти власну стратегію дій, знаходити та обцрунтовувати оптимальні рішення.

Ключові слова: модель, метод моделювання, підготовка майбутніх педагогів, професійна діяльність.

UDK 378

DOI: https://doi.org/10.17721/2415-3699.2020.11.02

O. Derkach, PhD student

Taras Shevchenko National University of Kyiv, Kyiv, Ukraine

\section{THE INFLUENCE OF STUDENT SELF-GOVERNMENT ON THE DEVELOPMENT OF UNIVERSITY AUTONOMY IN POLAND}

The article is devoted to the problem of studying the influence of student self-government bodies in Polish universities on the development of university autonomy. Student self-government in Europe is not a new phenomenon, dating back to the first medieval universities. Even then, the most talented students were involved in certain administrative functions, as well as in teaching as assistant professors. No wonder universities are considered a kind of model of civil society and in this regard preceded the modern type of European civilization.

The article considers the main competencies of student government in Poland. The Polish experience of leading higher education institutions in the field of activity and functioning of student self-government as one of the social institutions of society, which is extremely interesting and useful for Ukraine, is analyzed. The organizational and legal bases of functioning of public student associations in the academic environment of Poland are analyzed. The role and place of the Polish Student Parliament in the system of state and public administration of higher education are shown. It is noted that the main body of student self-government in Poland is the Student Government Council. The Student Government Council is a body of resolution consisting of nine students selected in a general election. For student activities, this is approximately what the Seimas is for public authorities.

The brightest and most significant are the main directions and tasks of student self-government bodies, the system of student selfgovernment activities in higher education institutions in Poland. A feature of student government in Poland is their strong material base and financial and legal independence from the administration of the educational institution. It is determined that the Polish system of student self-government starting from the legislative level and ending with the material side has significant differences from the Ukrainian, which are discussed in detail in the article.

Keywords: HEI, Poland, student self-government bodies, student parliament, university autonomy, quality of education.

Formulation of the problem. Ukraine's independence and the formation of a national education system are characterized by a significant revival in Ukraine's education system. As a result of significant changes in the work of higher education institutions, student self-government is entering a qualitatively new stage of its development. This is due to the entry of Ukrainian education into the Bologna Process and other EU structures. In this context, acquaintance with world achievements in the field of student self-government is on time, because modern reality has a number of common problems and is characterized by a number of general trends that are important for the optimization of educational practice in Ukraine. Today, Ukrainian students raise the issue of creating self- government bodies not as an idea, but as a practical tool for action and implementation of student ideas.

To date, Ukraine has clearly defined the European vector of socio-economic development. However, immediately becoming a leading European country is not a real task and achieving this goal requires time and building effective mechanisms for various areas and industries. That is why it is important and necessary for our country, in the process of European integration, to study the experience of Poland in various spheres of society, including in the development of student government. Because it unites Ukrainian youth, which is the engine of change that is happening today. Comparing the state of development of student self-government in Ukraine and Poland, we note

(C) Derkach O., 2020 